Xiangkun Li

Hubei University, People’s Republic of China

\title{
Transformative Model of Joint Education Program between Polish and Chinese Universities: Chance and Challenge
}

Key words: Joint education program, International Curriculum, Student mobility, Transformative model

A b stract

This paper attempts to address current and emergent issues on the internationalization of higher education which arise from major transformation in both Poland and China. Reflecting on the increased university student population and growing demand for overseas study, joint education programs approved for Chinese universities in partnership with foreign universities need to face global pressures and local realities, with a focus on the internationalization of curriculum for program affordability and mutual mobility. Transformative model of joint education program is identified for consideration of chances and challenges, based on the current practice of Hubei University in collaboration with an Australian university.

Higher education across the world has experienced dramatic changes in recent years. There is no doubt that it should be viewed in the global context and not merely from a domestic point of view. Internationalization of higher education is no longer just about the signing of international memoranda of understanding. Issues now include the internationalization of the curriculum, the increased competition for international students, the offering of dual degrees with foreign partners, and the setting up of branch campuses abroad. To survive and thrive in this global trend, new strategies and models become necessary as to guarantee a sustainable, successful future for universities and the students

\section{Large Increase of University Student Population}

China and Poland share a similar trend in terms of increased student population. According to the first quality report on higher education release by China's Ministry of Education on Thursday $8^{\text {th }}$ April 2016 (http://usa.chinadaily.com.cn/epaper/2016-04/11/ content_24441272.htm), China now has 2,900 colleges and universities across the country, which is second only to the United States. China's student population has risen exponentially over the past 70 years, growing from 117,000 in 1949 to a remarkable 37 million in 2015 - the world's largest student population. 
Polish higher education is considered as one of the most dynamically developing areas of social life. Over the past two decades, Polish universities have changed considerably, mainly because of the collaboration with other countries in the international arena. Poland now holds fourth place in Europe (after the United Kingdom, Germany and France) in terms of the number of people enrolled in higher education. The total student population at over 450 higher education institutions numbers almost 2 million.

\section{Growing Number of International Students}

The number of international students in both Poland and China continues to grow. According to the latest Central Statistical Office data, more than 57,000 foreigners study in Poland; a year before it was only 46 thousand people from abroad. In one year, Poland gained 11 thousand international students. This is over 23 percent increase. Students from abroad now represent approximately 4 percent of the total number of students in the country. The largest group of foreign students in Poland are Ukrainians (30,5 thousand), the second largest group are Belarusians (over 4.6 thousand), followed by Norwegians (1581), the Spanish (1407) and Swedes (1291). In the academic year 2014/15, over 83 percent of the total number of foreign students came to Poland from Europe. In addition, in Poland there are less than 7 thousand students from Asian, just over 1,200 from North and Central America, and slightly less than 1200 from Africa; there are also small groups of students from South America and Oceania (http:// www.go-poland.pl/news/number-international-students-poland-continues-grow).

While in China last year, a total of 397,635 foreign students from 202 countries and regions studied in 811 colleges, universities, research institutes and other educational institutions in 31 provinces, autonomous regions and municipalities across China (http://en.moe.gov.cn/ News/Top_News/201604/t20160420_239196.html).

This number was up 5.46 percent from the 2014 total of 377,054 . The number of countries and regions of origin of foreign students was basically equal to that of 2014. The top 10 were South Korea, the US, Thailand, India, Russia, Pakistan, Japan, Kazakhstan, Indonesia and France. Among those, South Korea, India, Pakistan and Kazakhstan have been growing most as sources of international students, each showing a year-on-year growth of over 10 percent.
Figure 1. Top 15 Countries of International Students Studying in China in 2015

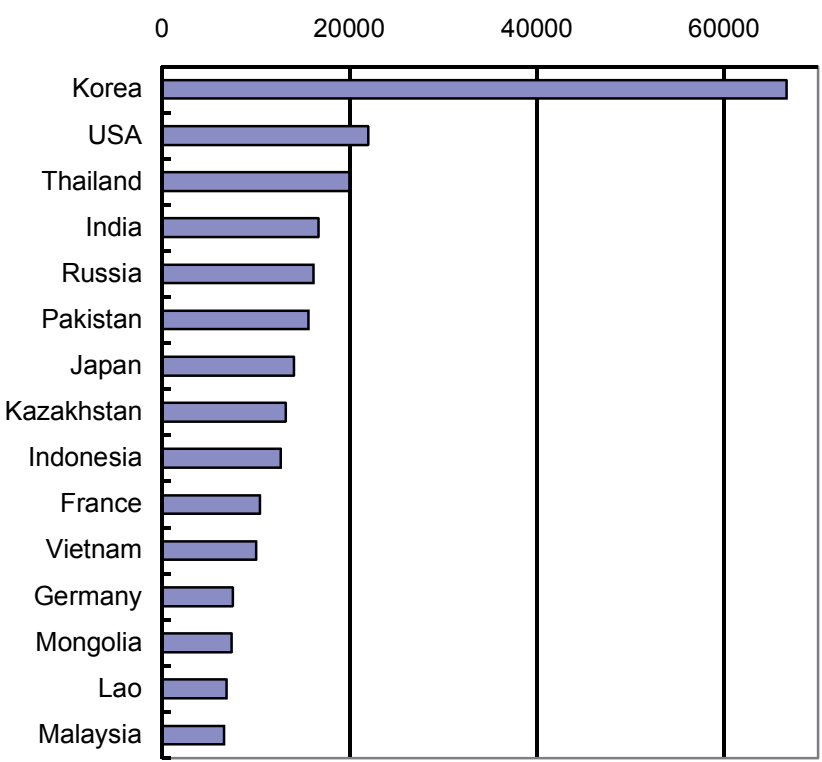

New initiative has been jointly launched by five Chinese government ministries to support international student to study in China, with a target population of 450,000 by the year 2017 .

Figure 2. Annual Number of International Students Studying in China

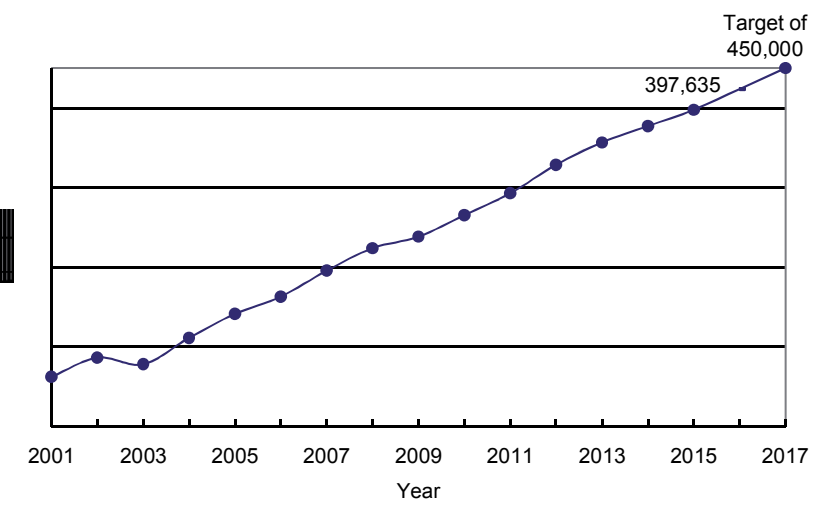

\section{Mutual Students to Each Other: China and Poland}

A brief report summarized by China's Ministry of Education on China-Poland Educational Cooperation and Exchange (http://www.moe.edu.cn/publicfiles/business/htmlfiles/moe/moe_853/201005/87462.html) shows (as in Chinese) that as many as 865 Polish students studied in China for the year 2013, amounting to a total of 1072 Polish students studying in China since 1950, when there was only 9 Polish students. 
The same report describes that up to the end of year 2013, the total number of Chinese people who studied in Poland reaches 1210, including 605 people studying in Poland for the year 2013.

An interesting issue emerges here as what reason causes such a figure for mutual students to each other, especially so low for Chinese studying in Poland, yet the two countries separately keep an increase in both domestic and international student population.

According to statistics released by China's Education Ministry, a total of 523,700 Chinese people went overseas to study in 2015, marking a 14 percent year-on-year rise. Along with this rise, what strategy could be identified so as to increase the percentage of Chinese people to study in Poland? Or to attract more Polish students to study in China?

Annual Number of Chinese People Studying Abroad

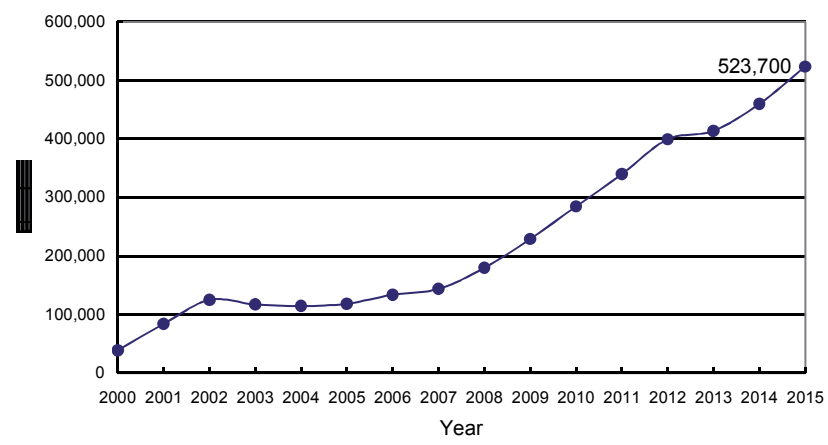

\section{Joint Education Program between Chinese and Polish Universities}

Joint education programs between Chinese and foreign universities started to emerge with one important legislation The Regulations of PRC on Chinese-Foreign Cooperation in Running Schools (Zhongwai Hezuo Banxue Tiaoli) enacted in. The new regulations together with detailed measures provide the legal framework and apply to international partnerships providing higher education and foreign qualifications within China.

Up to 2015, more than 1000 degree programs has been approved by China's Ministry of Education. Student population with these joint programs amounts to 460,000 , with a total of more than $1,600,000$ graduates, and with an annual intake of more than 100,000 students.

As the English language is an important of instruction and research in the internationalization of higher education, a phenomenon that is clearly illustrated by the fact that most of the joint education programs are in partnership with universities in such English-speaking countries as the United Kingdom (22.4\%), the United States (20.2\%), Australia (13.6\%), and Canada (5.9\%).

It is noteworthy that in the past four years four such joint education programs, approved by China's Ministry of Education, are in collaboration with Polish universities, though the number standing as a 0.4 percentage.

Figure 3. MOE Approved Joint Programs between Chinese and Foreign Universities

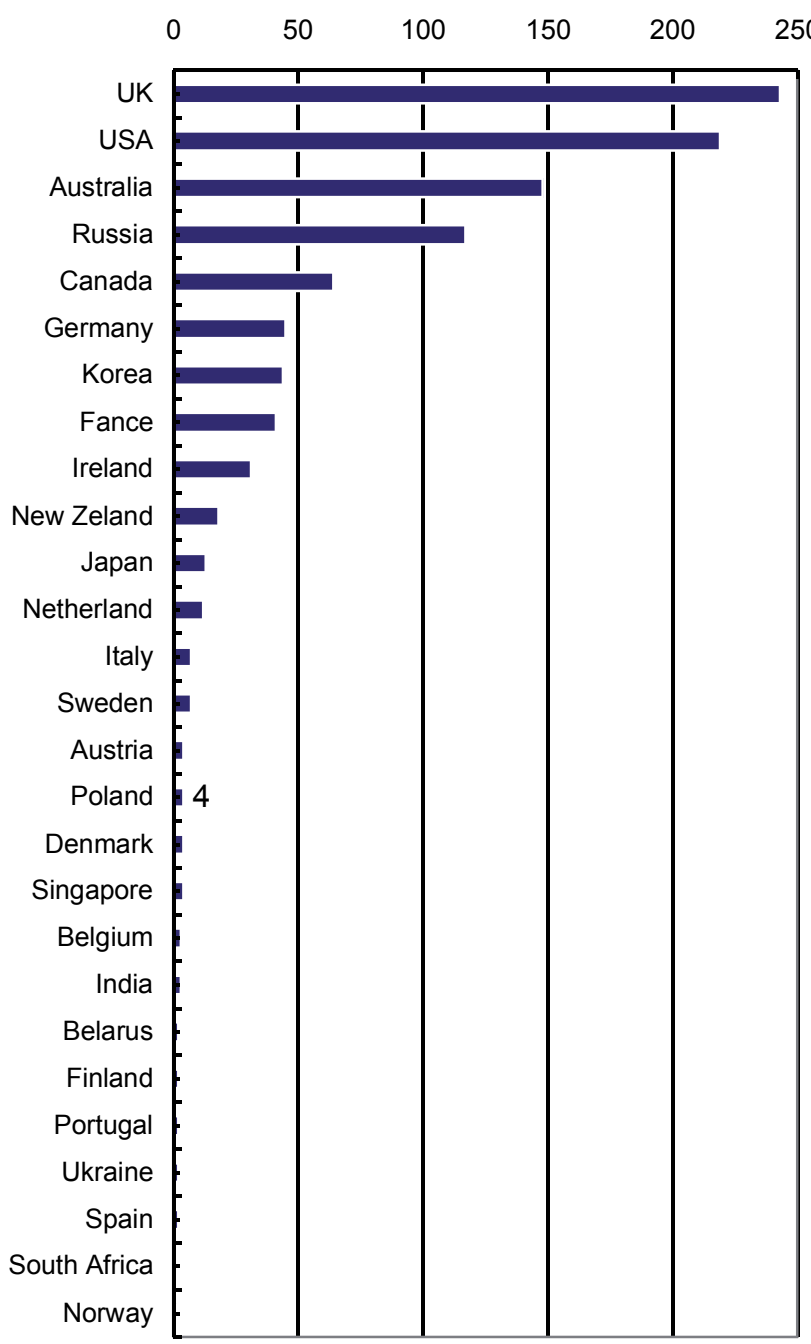

Joint education programs between Chinese and foreign universities vary in accordance with the university's strength, location, size, resources, breadth of international connections, and its ability to attract local Chinese students as well as foreign faculty with an international perspective in a globally interconnected world.

Poland plays an active part already in the Bologna Process. Owing to the introduction of three-stage education as well as the European Credit Transfer System, both Polish students and foreigners studying in Poland remain fully mobile and can continue education elsewhere in the European Union without any problems. 
Within the Erasmus Program alone, which has been running for over 20 years now, almost 30 thousand foreign students have come to study in Poland while almost 100 thousand students from Poland have taken part of their education in another country within the European Union.

Polish universities offer more than 200 high quality study programs as an integral part of the European Higher Education Area. Most schools offer their courses also in foreign languages. Foreign students coming to Poland can expect a most attractive and diversified education offer meeting the high European standards.

Thus more issues need to be raised hereof with what reason there remain only four joint programs with Polish universities, with what purpose for Polish universities to join in such an education program, and with what likelihood such joint education programs can become more than the actual number.

Table 1. Joint Education Program between Polish and Chinese Universities

\begin{tabular}{|c|c|c|c|c|}
\hline $\begin{array}{c}\text { Polish } \\
\text { University }\end{array}$ & $\begin{array}{c}\text { Chinese } \\
\text { University }\end{array}$ & $\begin{array}{c}\text { Approved } \\
\text { Joint } \\
\text { Program }\end{array}$ & $\begin{array}{c}\text { Approved } \\
\text { Year }\end{array}$ & $\begin{array}{c}\text { Approved } \\
\text { Enrolment }\end{array}$ \\
\hline $\begin{array}{c}\text { University } \\
\text { of Lodz }\end{array}$ & $\begin{array}{c}\text { Zhengzhou } \\
\text { University }\end{array}$ & Economics & 2012 & 200 \\
\hline $\begin{array}{c}\text { University } \\
\text { of Warsaw }\end{array}$ & $\begin{array}{c}\text { Zhengzhou } \\
\text { University }\end{array}$ & $\begin{array}{c}\text { Applied } \\
\text { Psychology }\end{array}$ & 2013 & 100 \\
\hline $\begin{array}{c}\text { University } \\
\text { of Social } \\
\text { Sciences } \\
\text { and }\end{array}$ & $\begin{array}{c}\text { Zhengzhou } \\
\text { University } \\
\text { of } \\
\text { Aumanities }\end{array}$ & $\begin{array}{c}\text { Product } \\
\text { Design }\end{array}$ & 2015 & 100 \\
\hline $\begin{array}{c}\text { Warsaw } \\
\text { University } \\
\text { Technology }\end{array}$ & Qinzhou & $\begin{array}{c}\text { Electronic } \\
\text { Unformation } \\
\text { Engineering }\end{array}$ & 2015 & 120 \\
\hline
\end{tabular}

\section{Affordability of Joint Education Program}

In the last two decades, the political, cultural and economical pressures drive universities to radical changes depending on information age and globalization (Kennedy, 2003; Milliken, 2004; Mora, 2001). Inevitable transformation in higher education faces global pressures as well as local realities.

Though numbers of students that cross borders are increasing and institutional activities and strategies for internationalization have become more elaborate, student mobility is yet mostly influenced and constrained by a complex matrix of cultural ties, demographics, economic factors, political climate, educational infra- structure in the country, available technology, popular perceptions, and the formal policies of institutions and governments (Beytekin and Arslan, 2012).

Scholarship, whether governmental or institutional, offers only a small number of chances. More than $90 \%$ of Chinese people studying overseas in 2015 are self-funded.

Figure 4. Number and Percentage of the Funding Source in 2015

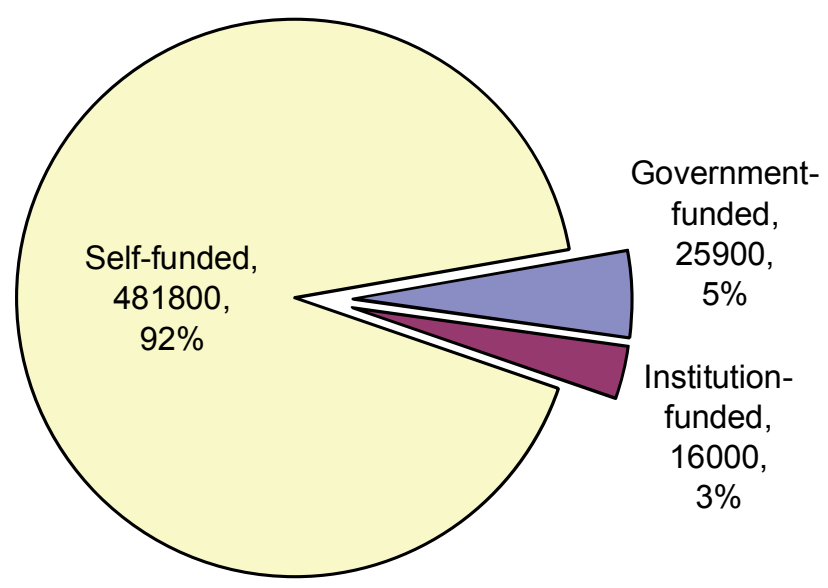

Likewise in 2015, about 40,600 foreign students, or 10.21 percent of the foreign student population, received Chinese government scholarships, though the number of students receiving a scholarship increased 9.9 percent from 2014.

A joint education program thus needs mutual commitment by the two counterpart universities for the final benefit of the students receiving an internationalized education with a possibility. This means offering students an education that is more affordable. Given their aims and rationales include networking for mutual understanding and intercultural learning, for achieving academic excellence, and for providing assistance to build capacity in other countries, universities should not only grapple but also struggling with economic pressures to define the value of a degree, increase college completion rates, and provide high-quality education, while lowering the actual costs.

Affordability will thus attract and inspire more students into the program and then increase student mobility even in a final mutual way. 


\section{Transformative Model of Joint Education Program}

A transformative model is generated as the outcome of more than ten years of practice at Hubei University in collaboration with the University of Canberra, Australia, initially based on Communication Studies and currently on International Studies.

\section{Internationalizing the curriculum}

Student mobility is for the purpose of intercultural learning, and any scholarship is sponsored for learning one by one a particular course from the designated curriculum, leading to the completion of the whole program.

Internationalizing the curriculum involves providing students with global perspectives of their discipline and giving them a broader knowledge base for their future careers. An internationalized curriculum and co-curriculum ensure that all students are exposed to international perspectives and build global competence.

Since the discipline of International Studies is already $\mathrm{z}$ itself to internationalization more easily, this joint program's hallmarks include:

- Critical thinking;

- Communication competence;

- Multilingual proficiency;

- Intercultural understanding;

- Digital literacy;

- Interdisciplinary learning;

- Team building;

- Problem solving;

- Global citizenship.

Curriculum content and the pedagogical approaches used by teachers are key vehicles for improving teaching and learning for all students. Curriculum design for the first two years, adopting mutually chosen textbooks written in English, requires a delivery or joint delivery in English so as to match and link with the adequate level into the Australian university.

Year One:

International Studies

Introduction to Communication

Critical Thinking

Introduction to English-Speaking Countries

Introduction to International Relations

Global History

Media Communication

Public Speaking
Plus English Reading, Writing, Listening, and Speaking

Year Two:

Globalization

Intercultural Communication

International Communication

Social Research Methods

Organizational Communication

World Politics

International Organization

Public Relations

International Management

International Etiquette

Plus Second Foreign Language (Portuguese, Spanish, or Russian)

\section{Challenge and Chance}

The most obvious challenge is that internationalization of the curriculum needs so far to take into consideration all the local domestic requirements. Thus the students in the program undertake at the same time the following study patterns for the first two years:

Semester 1 of Year One:

Fundamentals of Law

College English

College Physical Education

Computing Foundation

Plus Military Training

Semester 2 of Year One:

Chinese Modern History

College English

College Physical Education

Writing for Practical Purposes

Semester 1 of Year Two:

Theory of Socialism

College English

College Physical Education

Semester 2 of Year Two:

Marxist Principles

College English

College Physical Education

Yet the transformation turns out to be inspiring, as successful students who finish the first year of study can reach an average IELTS score of 6.5 or even higher. With the second year plus adequate financial support, 
they can get a chance of admission into the Australian university's second level of learning. Excellent students can extend their international reach soon after they finish three semesters of study at Hubei University.

The joint education program with its international curriculum delivered in English also attracts international exchange students to join in the same class, resulting in the actual international and intercultural learning and interaction, which helps in return to provide Chinese and international students as well as academics with a set of values and skills to operate in diverse intercultural environments. These values, skills and knowledge represent the hallmarks in relation to graduate attributes and global citizenship with an acknowledgement that graduates today will need the resilience and competencies to communicate and compete in a rapidly changing, complex global workforce and world.

This transformative model can be also applicable to a possible joint education program with an interested Polish university, especially within a discipline of humanities, with Polish language replacing the English reading, writing, listening, and speaking. It will become more attractive and more affordable to Chinese students, as well as mutually rewarding once Polish academics join in the delivery and Polish students join in the class for the first two years, no matter in Polish or in English.

\section{References}

Beytekin O.F., Arslan H. (2012). Transformation in Higher Education: The Case of Kocaeli University. Journal of Alternative Perspectives in the Social Sciences. 4(1).

Kennedy J.K. (2003). Higher Education Governance as a Key Policy Issue in the $21^{\text {st }}$ Century. Educational Research for Policy and Practice. $2(55) .70$.

Milliken J. (2004). Thematic Reflections on Higher Education Postmodernism versus Professionalism in Higher Education. Higher Education in Europe. XXIX(1). 9-18.

Mora J.G. (2001). Governance and Management in the New University. Tertiary Education and Management. (7). 95-100.

http://usa.chinadaily.com.cn/epaper/2016-04/11/content_24441272. htm

http://www.go-poland.pl/news/number-international-students-poland-continues-grow

http://en.moe.gov.cn/News/Top_News/201604/t20160420_239196. html 